Transportation Research Forum

Determinants of Motor Vehicle Fatalities: A Kansas Case Study

Author(s): Michael W. Babcock, Thomas J. Zlatoper, and Andrew M. Welki

Source: Journal of the Transportation Research Forum, Vol. 47, No. 1 (Spring 2008), pp. 89-106

Published by: Transportation Research Forum

Stable URL: http://www.trforum.org/journal

The Transportation Research Forum, founded in 1958, is an independent, nonprofit organization of transportation professionals who conduct, use, and benefit from research. Its purpose is to provide an impartial meeting ground for carriers, shippers, government officials, consultants, university researchers, suppliers, and others seeking exchange of information and ideas related to both passenger and freight transportation. More information on the Transportation Research Forum can be found on the Web at www.trforum.org. 


\title{
DETERMINANTS OF MOTOR VEHICLE FATALITIES: A KANSAS CASE STUDY
}

\author{
by Michael W. Babcock, Thomas J. Zlatoper, and Andrew M. Welki
}

This paper analyzes the determinants of motor vehicle fatalities in Kansas. The objectives of the study include the following:

- Conduct a literature review of motor vehicle safety studies.

- Formulate a theoretical model of the determinants of motor vehicle fatalities.

- Estimate the statistical significance of the various determinants.

- Compare the empirical results of the study to other recent state studies of motor vehicle fatalities.

The unemployment rate had the expected inverse relationship to fatalities but was statistically significant in only two of seven estimated models. Alcohol consumption and the speed limit on rural interstate highways had the expected positive relationship to fatalities. Other variables that were statistically significant included Kansas seat belt law dummy, the proportion of young and old drivers to the rest of the Kansas population, and the ratio of rural to urban driving. The study measured the effect of three measures of highway safety law enforcement on fatalities: Kansas police per 10,000 population, Kansas police per 100 miles of road, and Kansas per capita expenditure for police protection. All three had the expected negative sign and were highly significant.

\section{INTRODUCTION}

The causes of transportation accidents and fatalities have been and continue to be a major concern of economists and policymakers. Research on this issue has involved virtually all modes of transportation including motor vehicles, water carriers, railroads, and airlines. Many of these studies have been national in scope with relatively fewer investigations focused on determinants of accidents and fatalities at the state level. This study partially fills this research gap by empirically estimating the determinants of motor vehicle fatalities in the state of Kansas, with special emphasis on the impact of highway safety law enforcement on fatalities. Kansas plays an important role in national highway transportation. Kansas has the fourth highest total road miles in the nation, exceeded only by California, Texas, and Illinois. ${ }^{1}$ The state ranks second in the nation to Texas in total miles of rural roads. Kansas ranks exactly in the middle (25th) of states in motor vehicle fatalities per 100 million vehicle miles and per capita expenditure for police protection. However, the state ranks eighth in police employment per 10,000 population. (U.S. Department of Justice 2005 and U.S. Department of Transportation 2006). While the results of the study are unique to Kansas, they may interest policymakers in other states with respect to public policies such as speed limits, seat belt laws, and enforcement of traffic laws.

The objectives of the paper are as follows:

- conduct a literature review of motor vehicle safety studies

- formulate a theoretical model of the determinants of motor vehicle fatalities

- estimate the statistical significance of the various determinants of fatalities

- compare the empirical results of the study to other recent state studies of motor vehicle fatalities.

The objectives are accomplished using time series econometric models of the determinants of Kansas motor vehicle fatalities during the 1970-2005 period. 


\section{TRENDS IN KANSAS MOTOR VEHICLE FATALITIES}

Figure 1 plots annual Kansas motor vehicle fatalities for the 1970-2005 period. Consistent with national trends, fatalities in Kansas have been declining, falling from 657 in 1970 to 428 in 2005, a $34.9 \%$ decline. The data in Figure 1 are consistent with the hypothesis that motor vehicle fatalities decline during economic recessions (Robertson 1984), and are inversely related to the unemployment rate (Partyka 1984). Fatalities fell from 623 in 1973 to an average of 518 in the 1974-1975 recession. During the recession period of 1980-1982, Kansas motor vehicle fatalities declined from 595 in 1980 to 580 and 498 in 1981 and 1982 respectively. Kansas motor vehicle fatalities averaged 456 in 1988-1989, but fell to 444 in 1990 and 409 in 1991 during the 1990-1991 recession. In the most recent recession (2000-2001), fatalities dropped from 537 in 1999 to 461 and 494 in 2000 and 2001 respectively.

Figure 2 displays annual Kansas motor vehicle fatalities per 100 million Kansas vehicle miles (hereafter referred to as the fatality rate). The fatality rate plunged from 4.91 in 1970 to 1.6 in 1992 , a $67.3 \%$ decrease. The fatality rate remained relatively constant for the next 10 years, varying from 1.6 to about 1.9 . In the 2002-2005 period the fatality rate dropped from 1.8 (2002) to 1.44 (2005), a $20 \%$ decline. The decline in the Kansas fatality rate for the entire $1970-2005$ era was $70.7 \%$.

\section{LITERATURE REVIEW}

As suggested by Loeb and Clarke (2007), many determinants of motor vehicle accidents and fatalities have been investigated in previous studies. These include economic variables such as real gross domestic product (GDP) and the unemployment rate; population characteristics such as age, gender, and race; roadway characteristics such as the ratio of rural to urban vehicle miles, interstate highway travel, proximity to hospitals, degree of congestion, speed limits, average speed, speed variation, and vehicle miles driven; weather conditions, traffic law enforcement, safety improvements of motor vehicles, and alcohol consumption.

The amount of driving is directly related to the level of economic activity. Thus, during recessions, driving activity falls leading to fewer accidents and deaths. Partyka (1984), Evans and Graham (1988), Fowles and Loeb (1995), and Welki and Zlatoper (2007) found evidence of a negative relationship between the unemployment rate and various categories of highway fatalities. Loeb and Clarke (2007) point out the impact of income on accidents and fatalities is theoretically indeterminate. As income decreases, driving activity decreases resulting in fewer fatalities. Also, a rise in the unemployment rate will decrease income and fatalities. However, as income falls the demand for safety declines resulting in an increase in fatalities, so the net effect has to be determined empirically.

Motor vehicle fatalities are directly related to the amount of vehicle miles traveled. Loeb et al. (1994, 25-26) cited several studies reporting significant positive relationships between travel volume variables and highway deaths.

Driver characteristics also influence highway fatalities. Loeb et al. (1994, 20-21), Welki and Zlatoper (2007), and Fowles and Loeb (1989) found that greater alcohol consumption (assumed to be directly correlated to alcohol consumption of drivers) leads to more highway accidents and deaths. Fatal accident rates in the United States are highest for young drivers, decline with age, and then rise for the oldest drivers (Loeb et al. 1994, 23; Fowles and Loeb 1995; and Welki and Zlatoper 2007). This pattern of accident rates may be due to younger drivers' propensity to take more risks and elderly motorists' loss of driving-related physical skills, such as eyesight and speed of reflexes (Evans 1991). While this suggests that highway fatalities increase with the amount of driving by the youngest and oldest motorists, the empirical evidence on this hypothesized relationship has been mixed (Loeb et al. 1994, 23-25). Empirical evidence also indicates that male drivers are more likely to be involved in motor vehicle accidents (Levy and Asch 1989). 
Figure 1: Kansas Motor Vehicle Traffic Fatalities (1970-2005)

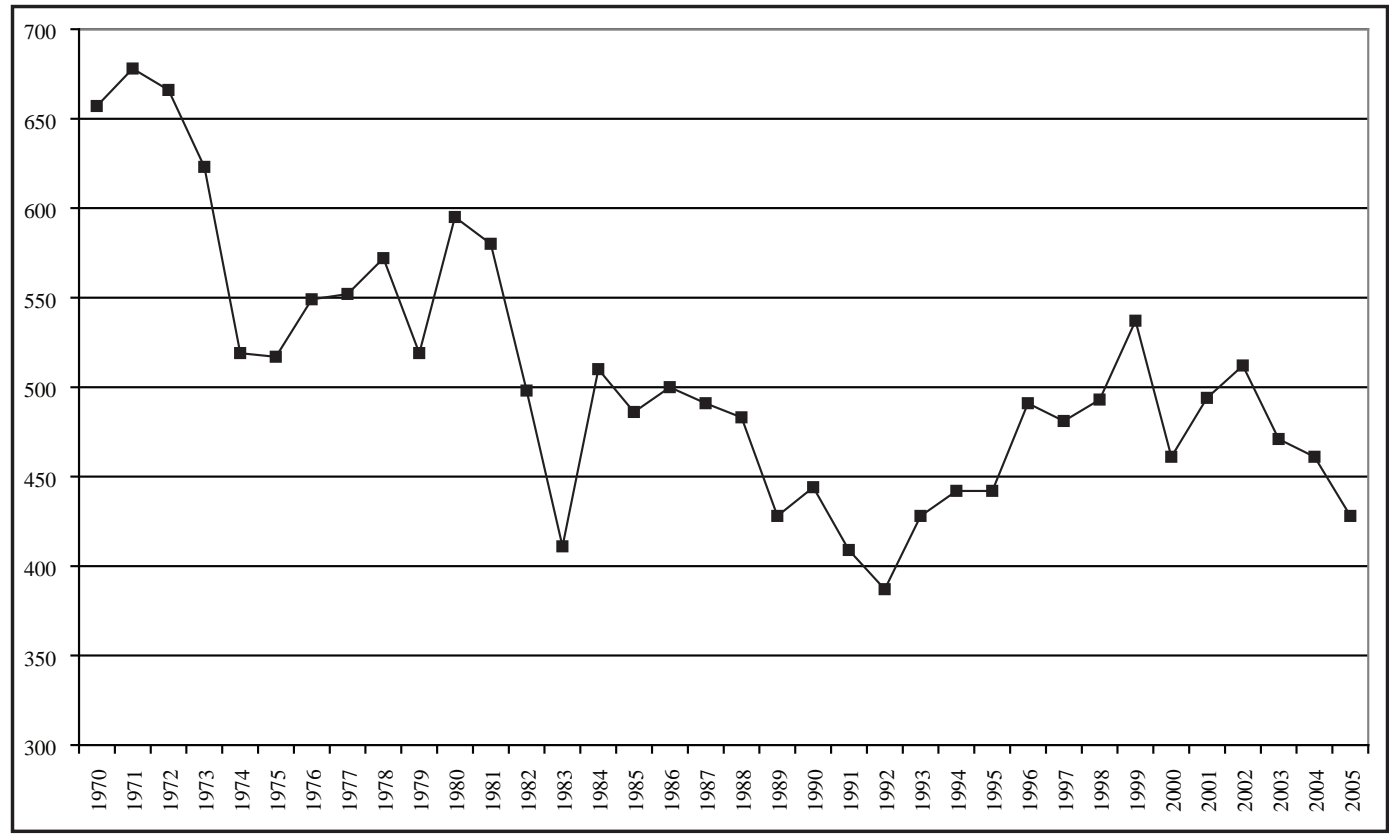

Figure 2: Kansas Motor Vehicle Traffic Fatalities Per 100 Million Vehicle Miles (1970-2005)

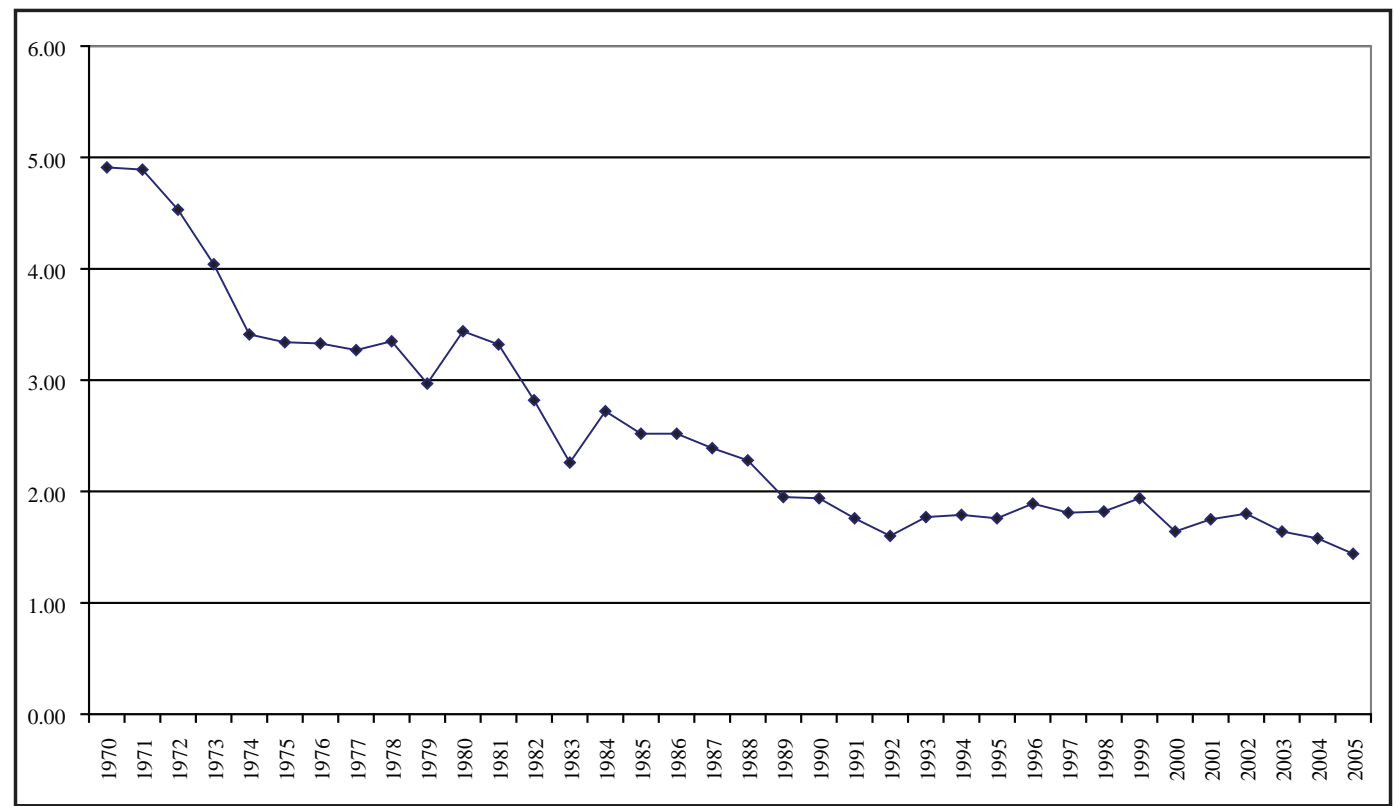


Highway characteristics such as interstate highway usage, ratio of rural to urban vehicle miles, speed limits, and speed and speed variance affect accidents and deaths. With regard to the latter there is some empirical evidence that higher speed and greater speed variation both increase highway deaths (Loeb et al. 1994, Lave 1985, Fowles and Loeb 1989, 1995, Levy and Asch 1989, and Welki and Zlatoper 2007). Loeb et al. (1994, 65-67) cited research confirming the lifesaving effect of reducing the national speed limit to $55 \mathrm{mph}$ in 1973 and the increase in fatalities related to increasing the limit to $65 \mathrm{mph}$ on certain roads. The opposing view is that a higher speed limit reduces driving time for given trip lengths and reduces the probability of a fatigue induced accident. Fatal accidents occur more frequently in rural areas than in urban areas (NHSTA 2002, 52). Several studies found a significant inverse relationship between motor vehicle fatality measures and the proportion of travel on urban highways (Loeb et al. 1994, 52).

Highway safety regulation enforcement helps create safer driving conditions by enforcing speed limits, seat belt laws, and intoxicated driver laws. Alexander (1992) found that the number of highway police officers per mile of road had a statistically significant negative relationship with various truck accident rates. Zlatoper (1991) found a significant inverse relationship between per capita motor vehicle fatalities and per capita expenditures on highway law enforcement and safety.

Motor vehicle inspections could make roads safer by removing unsafe vehicles from the highways or if vehicle safety defects triggered by inspections are remedied, resulting in fewer accidents and deaths. Kraas (1993) found a statistically significant negative relationship between truck-at-fault accidents per vehicle mile and roadside inspections per vehicle mile. Loeb (1990) reported evidence that motor vehicle inspections have a statistically significant life-saving effect. On the other hand, Merrell et al. (1999) found no evidence that state automobile safety inspections reduce fatality or injury rates. Keeler (1994) found that vehicle inspection programs reduced motor vehicle fatalities in 1970, but not in 1980 . This may be due to changes in the age of the automobile stock.

To encourage seat belt use, states have enacted mandatory usage laws. According to U.S. General Accounting Office (1992) and Loeb (1995), state seat belt laws reduce highway accidents, injuries, and deaths. Loeb (1993) and Loeb (2001) found that the effectiveness of the California and Maryland seat belt laws varied with the type of injury examined. In contrast, Welki and Zlatoper (2007) found no evidence that Ohio's secondary seat belt law saves lives.

Motor carrier deregulation occurred in 1980 with the passage of the Motor Carrier Act of 1980. The empirical evidence regarding the impact of motor carrier deregulation and trucking accidents is mixed. Adams (1989), Daicoff (1988), and Kraas (1993) found evidence that deregulation reduced safety in the trucking industry. On the other hand, Moore (1989), Viscusi (1989), and Alexander (1992) found that deregulation did not result in a decline in various measures of motor carrier safety. Loeb and Clarke (2007) did not find evidence that deregulation resulted in an increase in truck accidents.

\section{MODEL}

The model in this study is based on empirical findings of prior studies of motor vehicle safety, and it incorporates some of the explanatory variables discussed above. Following the approach of Welki and Zlatoper (2007), the general form of the model is as follows:

(1) Motor Vehicle Fatalities $=\mathrm{f}$ (economic conditions, driver characteristics, government traffic regulations, location of driving, traffic law enforcement, other factors)

Table 1 contains the variables of the Kansas motor vehicle fatality model. All the variables in the model pertain to Kansas. The dependent variable (Deaths) is defined as annual motor vehicle fatalities in the state of Kansas. All variables are measured in annual frequency for the 1970-2005 period.

The amount of driving is directly related to the level of economic activity. Economic downturns lead to diminished driving and fewer accidents and fatalities. Thus, the theoretically expected sign 
of the unemployment rate is negative in this model. Exposure to accidents increases with the amount of driving. Thus, an increase in vehicle miles of travel should lead to more accidents and deaths, resulting in a positive expected sign of vehicle miles. As noted above, fatal motor vehicle accidents occur more frequently in rural areas than in urban areas, possibly due to relatively higher speeds in rural areas. Consequently, the theoretically expected sign of RUvehmile is positive in this model.

Table 1: Kansas Motor Vehicle Model-Variable Definitions

\begin{tabular}{|c|c|}
\hline Variable & Definition \\
\hline Deaths (Dependent Variable) & Kansas motor vehicle fatalities \\
\hline Urate & Kansas unemployment rate (percent) \\
\hline Vehmile & Kansas vehicle miles of travel (millions) \\
\hline RUvehmile & Kansas ratio of rural vehicle miles to urban vehicle miles \\
\hline Alconsum & $\begin{array}{l}\text { Kansas apparent per capita ethanol consumption, all } \\
\text { beverages (gallons) }\end{array}$ \\
\hline Young & $\begin{array}{l}\text { Proportion of Kansas population (age } 15 \text { and older) in } \\
\text { the } 15-24 \text { year age group }\end{array}$ \\
\hline Old & $\begin{array}{l}\text { Proportion of the Kansas population (age } 15 \text { and older) } \\
\text { in the } 65 \text { years and older age group }\end{array}$ \\
\hline ynold & $\begin{array}{l}\text { Proportion of Kansas population (age } 15 \text { and older) in } \\
\text { the } 15-24 \text { year age group plus the } 65 \text { years of age and } \\
\text { older group }\end{array}$ \\
\hline Splimit & $\begin{array}{l}\text { Kansas maximum speed limit on rural interstate } \\
\text { highways (miles per hour) }\end{array}$ \\
\hline Seatbelt & $\begin{array}{l}\text { Kansas seat belt law dummy variable, equals } 1.0 \text { for } \\
1987-2005,0 \text { for other years }\end{array}$ \\
\hline Popop & Kansas police per 10,000 population \\
\hline Poroad & Kansas police per 100 miles of Kansas road \\
\hline Poexp & Kansas real per capita expenditure for police protection \\
\hline Trend & Time trend ( 1 to 36$)$ \\
\hline
\end{tabular}

Many previous studies have found a positive relationship between alcohol consumption and motor vehicle accidents and fatalities. The youngest and oldest drivers have the most fatal accidents, suggesting a positive relationship between Deaths and independent variables Young, Old, and ynold. However, the empirical evidence regarding the hypothesized positive relationship has been mixed (Loeb et al. 1994, 23-25). Thus, the theoretically expected sign is indeterminate.

As noted above, there are opposing theoretical viewpoints regarding the relationship of fatalities to the speed limit on rural interstate highways. Therefore, the expected sign is theoretically 
indeterminate. Empirical studies have found that seat belt laws reduce the number of motor vehicle serious injuries and deaths (Loeb 1993 and 1995).

Three highway safety regulation enforcement variables are included in the model: Popop, Poroad, and Poexp. Enforcement of highway safety laws, such as arrests for speeding and drunk driving as well as citations for failure to fasten seat belts, help establish safer driving conditions and lead to fewer fatalities. Thus, the theoretically expected sign of Popop, Poroad, and Poexp is negative. $^{2}$

A linear time trend represents factors that could impact Kansas highway fatalities but are not explicitly accounted for by the model. Peltzman (1975) pointed out that excluded factors could include the quality of roads, the private demand and supply of improved vehicle design, the demand and supply of vehicle maintenance, and the quality of trauma health care. He noted that as these factors improve over time, motor vehicle fatalities will decrease. Peltzman (1995) and Loeb and Clarke (2007) hypothesized that the time trend serves as a partial proxy for permanent income, resulting in an inverse relationship between the trend and motor vehicle fatalities.

\section{DATA}

Data for the dependent variable and explanatory variables in Table 1 are for the 1970-2005 period. The data source for Kansas motor vehicle fatalities, rural vehicle miles, urban vehicle miles, and total vehicle miles is U.S. Department of Transportation, Highway Statistics (1970-2005 issues).

The unemployment rate for 1970-1975 comes from Annual Report of the Governor published by the State of Kansas. Unemployment rate data for 1976-2005 are from Kansas Department of Human Resources, Labor Stats (http://laborstats.dol ks.gov).

The data source for per capita alcohol consumption is National Institute on Alcohol Abuse and Alcoholism (http://www niaaa.nih.gov/resources/databaseresources/quickfacts/alcoholsales/ consum04.htm).

Data for the age distribution of population variables (Young, Old, ynold) are reported in several U.S. Bureau of Census publications. The source for 1970-1979 is U.S. Bureau of the Census, Intercensal Estimates of the Resident Population 1970 to 1980 (http://www.census.gov). For the 1980-1989 era the source is U.S. Bureau of the Census, Resident Population of States by Five-Year Age Groups and Sex (http://www.census.gov). For the 1990-1999 interval, the data are found in U.S. Bureau of the Census, Population Estimates for the U.S. Regions and States by Five-Year Age Groups and Sex: Time Series Estimates, July 1, 1990 to July 1, 1999, and April 1, 1990, Census Counts (http://www.census.gov). Data for 2000-2005 are from U.S. Bureau of the Census, Annual Estimates of the Population by Age and Sex for Kansas, April 1, 2000 to July 1, 2006 (http://www. census.gov).

For the maximum speed limit on rural highways (Splimit) the data source for 1970 to 1995 was personnel at the Kansas Department of Transportation. Insurance Institute for Highway Safety, Maximum Posted Speed Limits for Passenger Vehicles as of April 1, 2007 (http://www.iihs.org/laws/ state_laws/speed_limit_laws.html) is the data source for the 1996-2005 period.

The Kansas secondary seat belt law became effective on July 1, 1986, and applies to front seat passengers in passenger cars and vans. The information for the seat belt dummy variable is reported in U.S. Department of Transportation (1998), Traffic Safety Facts: A Compilation of Motor Vehicle Crash Data from the Fatality Analysis Reporting System and the General Estimates System.

The Kansas police protection variables (Popop, Poroad, and Poexp) are from a wide variety of data sources. Full-time equivalent police employment and per capita expenditure for police protection are from the same data sources. For 1970, the data are reported in U.S. Department of Justice, Sourcebook of Criminal Justice Statistics, 1973. For 1972-1974 the data can be found in U.S. Department of Justice, Trends in Expenditure and Employment Data for the Criminal Justice System (1971-1977 issues). The data for 1971 and 1975-1979 is in U.S. Department of Justice, Justice Expenditure and Employment in the U.S., 1971-1979. For the 1980s, the data is reported 
in U.S. Department of Justice, Justice Expenditure and Employment Extracts for various years. U.S. Department of Justice, Justice Expenditure and Employment Extracts: Data from the Annual General Finance and Employment Surveys is the source for the 1992-2004 period. Data for a few of the years is estimated by linear trend regression or interpolation. The Kansas population data needed to calculate Popop and Poexp comes from the same data sources as enumerated above for the age distribution of the population variables. The Consumer Price Index required to calculate Poexp comes from Economic Report of the President 2007. Kansas public road miles required to calculate Poroad are from the same data sources as those for Kansas motor vehicle fatalities and vehicle miles.

The descriptive statistics for the variables in the Kansas motor vehicle fatality model are in Table 2. The data in the table indicate that the mean of annual motor vehicle fatalities (Deaths) in Kansas during the 1970-2005 time period was about 506. For the economic factors in the model, the mean unemployment rate (Urate) is $4.56 \%$ and the mean number of annual vehicle miles (Vehmile) is about 21,433 million.

Table 2: Statistical Summary of Variables in Kansas Motor Vehicle Fatality Model

\begin{tabular}{|c|c|c|c|c|c|}
\hline Variable & Unit of Measure & Mean & $\begin{array}{c}\text { Standard } \\
\text { Deviation }\end{array}$ & $\begin{array}{l}\text { Maximum } \\
\text { Value }\end{array}$ & $\begin{array}{c}\text { Minimum } \\
\text { Value }\end{array}$ \\
\hline Deaths & Number of Deaths & 505.97 & 72.79 & 678 & 387 \\
\hline Urate & Percent & 4.56 & 0.87 & 6.34 & 3.0 \\
\hline Vehmile & Millions & $21,432.53$ & $5,103.59$ & 29,621 & 13,376 \\
\hline RUvehmile & Ratio & 1.30 & 0.189 & 1.687 & 0.921 \\
\hline Alconsum & Gallons & 1.84 & 0.11 & 2.05 & 1.59 \\
\hline Young & Percent & 21.30 & 3.0 & 25.67 & 18.21 \\
\hline Old & Percent & 17.01 & 0.536 & 17.97 & 16.25 \\
\hline ynold & Percent & 38.31 & 2.64 & 42.11 & 35.49 \\
\hline Splimit & Miles Per Hour & 63.89 & 7.38 & 75 & 55 \\
\hline Seatbelt & -- & 0.555 & 0.504 & 1 & 0 \\
\hline Popop & $\begin{array}{l}\text { Police per 10,000 } \\
\text { Population }\end{array}$ & 26.2 & 4.45 & 33.38 & 17.52 \\
\hline Poroad & $\begin{array}{l}\text { Police per } 100 \text { Miles } \\
\text { of Road }\end{array}$ & 4.91 & 1.14 & 6.675 & 2.941 \\
\hline Poexp & Dollars & 69.07 & 21.61 & 104.91 & 34.87 \\
\hline Trend & -- & 18.5 & 10.54 & 36 & 1 \\
\hline
\end{tabular}

For the driver characteristics, the mean per capita alcohol consumption is 1.84 gallons. The mean proportion of the age 15 and over population aged 15-24 (Young) is 21.3\% and for the age 65 and older group it is $17.01 \%$ (Old). Thus, these two population groups account for well over a third (38.31\%) of the Kansas population age 15 and over in the years studied.

The maximum speed limit on rural interstate highways (Splimit) and Kansas seat belt law (Seatbelt) represent government highway regulation in the analysis. The average speed limit during the 1970-2005 interval is reported as about 64 miles per hour, and the seat belt law was in effect a little over half of this period. The amount of travel on rural highways in Kansas exceeds that of urban highways in the years studied. The mean ratio of rural to urban vehicle miles (RUvehmile) is 1.3 .

Highway safety regulation enforcement is represented in the analysis by Kansas police per 10,000 population (Popop), police per 100 miles of Kansas road (Poroad), and Kansas real per 
capita expenditure for police protection (Poexp). Data in Table 2 indicate the mean of Popop is about 26, for Poroad the mean is approximately five, and for Poexp it is $\$ 69.07$.

\section{EMPIRICAL RESULTS}

All the independent variables in Table 2 can not be included in the same regression due to substantial multicollinearity among the regressors. For example, Vehmile and RUvehmile have correlation coefficients greater than 0.90 with five and six other explanatory variables, respectively. In addition, the three highway safety regulation enforcement variables also have high correlation coefficients with other explanatory variables and among themselves (see Appendix for correlation matrix).

Three regressors, Urate, Alconsum, and Splimit, do not have high correlation with other regressors or among themselves. Therefore, the estimated models in Table 3 each contain these three variables and one other explanatory variable.

The Durbin-Watson statistics for the seven estimated equations indicate the possibility of positive autocorrelation. Thus, the equations are corrected for autocorrelation using Newey-West standard errors (Newey and West 1987). The t-statistics in Table 3 use the corrected standard errors

Vehmile is deleted from the final estimations. The expected sign of this variable is positive, yet the correlation to Kansas motor vehicle fatalities is -0.68 . In the 1970-2005 period, Kansas motor vehicle fatalities fell about $35 \%$, while Kansas vehicle miles rose $69 \%$. Also Vehmile is highly correlated with a number of other independent variables. Variables Old and Young are added and jointly reflected in variable ynold. All variables except Seatbelt are expressed in natural logarithms, including the dependent variable. ${ }^{3}$

The equations in Table 3 have reasonably good fits with adjusted $\mathrm{R}^{2}$ 's ranging from 0.57 to 0.70 . In Model 1 the unemployment rate, $\log ($ Urate), has the theoretically expected negative sign, but is not statistically significant. Per capita alcohol consumption, $\log$ (Alconsum), has a negative sign but the variable is non-significant. The maximum speed limit on Kansas rural interstate highways, $\log ($ Splimit), has a positive sign and is statistically significant at the .01 level. Seatbelt has the expected negative sign and is highly significant.

For Model 2, $\log ($ Urate), has the expected negative sign but is non-significant. $\log ($ Alconsum) has the expected positive sign but is non-significant. $\log ($ Splimit), as in Model 1, is positive and significant at the .01 level. The combined proportion of the Kansas age 15 and over population in the age 15-24 and over 65 age groups, $\log$ (ynold), has a positive sign and is strongly significant.

In Model 3, $\log ($ Urate) again has the expected negative sign but is nonsignificant, while $\log ($ Alconsum) has the expected positive sign and is significant at the .01 level. $\log$ (Splimit) as in the previous two models has a positive sign and is highly significant. The Kansas ratio of rural to urban vehicle miles, $\log (\mathrm{RUvehmile})$, has the theoretically expected positive sign and is strongly significant.

For Model 4, $\log ($ Urate) has the expected negative sign and is statistically significant at the .05 level, while $\log ($ Alconsum) and $\log$ (Splimit) have the theoretically expected positive sign and are significant at the .01 level. Given the downward trend in Kansas motor vehicle fatalities, Log(Trend) has the appropriate negative sign and is highly significant.

Models 5, 6, and 7 focus on the effect of the highway safety regulation enforcement variables on Kansas motor vehicle fatalities. In Model 5, $\log ($ Urate) has the expected negative sign and is significant at the .05 level. Variables $\log ($ Alconsum) and $\log ($ Splimit) have highly significant positive coefficients. Kansas police per 10,000 population, $\log ($ Popop) has the theoretically expected negative sign and is significant at the .01 level.

$\log ($ Urate) has the expected negative sign in Model 6 but it is non-significant, while $\log$ (Alconsum) and $\log$ (Splimit) have expected positive signs and are statistically significant. Kansas police per 100 miles of Kansas road, $\log (\mathrm{Poroad})$, has the theoretically expected negative sign and is highly significant. 
Table 3: Empirical Results

Dependent Variable: $\log ($ Deaths)

\begin{tabular}{|c|c|c|c|c|c|c|c|}
\hline Variable & Model 1 & Model 2 & Model 3 & Model 4 & Model 5 & Model 6 & Model 7 \\
\hline Constant & $\begin{array}{c}3.929 * * \\
(3.54)\end{array}$ & $\begin{array}{c}-3.723 * * \\
(-3.71)\end{array}$ & $\begin{array}{c}2.908 * * \\
(4.42)\end{array}$ & $\begin{array}{c}3.973 * * \\
(7.08)\end{array}$ & $\begin{array}{c}4.987 * * \\
(7.53)\end{array}$ & $\begin{array}{c}3.389 * * \\
(5.35)\end{array}$ & $\begin{array}{c}4.319 * * \\
(5.10)\end{array}$ \\
\hline $\log ($ Urate $)$ & $\begin{array}{c}-0.0957 \\
(-1.26)\end{array}$ & $\begin{array}{c}-0.0166 \\
(-0.24)\end{array}$ & $\begin{array}{c}-0.0613 \\
(-0.80)\end{array}$ & $\begin{array}{c}-0.1128^{*} \\
(-2.45)\end{array}$ & $\begin{array}{c}-0.1543^{*} \\
(-2.00)\end{array}$ & $\begin{array}{c}-0.1249 \\
(-1.63)\end{array}$ & $\begin{array}{c}-0.0947 \\
(-1.26)\end{array}$ \\
\hline Log(Alconsum) & $\begin{array}{l}-0.0117 \\
(-0.03)\end{array}$ & $\begin{array}{c}0.2598 \\
(1.17)\end{array}$ & $\begin{array}{c}0.7565^{* *} \\
(3.34)\end{array}$ & $\begin{array}{c}0.9944 * * \\
(5.72)\end{array}$ & $\begin{array}{c}1.0402 * * \\
(4.59)\end{array}$ & $\begin{array}{c}1.0269^{* *} \\
(4.18)\end{array}$ & $\begin{array}{c}0.7624^{* *} \\
(2.89)\end{array}$ \\
\hline $\log ($ Splimit $)$ & $\begin{array}{c}0.621^{* *} \\
(2.84)\end{array}$ & $\begin{array}{c}0.644 * * \\
(5.36)\end{array}$ & $\begin{array}{c}0.6574 * * \\
(4.74)\end{array}$ & $\begin{array}{c}0.523 * * \\
(4.54)\end{array}$ & $\begin{array}{c}0.7219^{* *} \\
(5.65)\end{array}$ & $\begin{array}{c}0.7626^{* *} \\
(5.74)\end{array}$ & $\begin{array}{c}0.7506^{* *} \\
(4.56)\end{array}$ \\
\hline Seatbelt & $\begin{array}{c}-0.2512 * * \\
(-7.37)\end{array}$ & -- & -- & -- & -- & -- & -- \\
\hline Log(ynold) & -- & $\begin{array}{c}1.9352 * * \\
(11.06)\end{array}$ & -- & -- & -- & -- & -- \\
\hline Log(RUvehmile) & -- & -- & $\begin{array}{c}0.8356^{* *} \\
(9.48)\end{array}$ & -- & -- & -- & -- \\
\hline $\log ($ Trend) & -- & -- & -- & $\begin{array}{c}-0.1369 * * \\
(-13.54)\end{array}$ & -- & -- & -- \\
\hline Log(Popop) & -- & -- & -- & -- & $\begin{array}{c}-0.6672 * * \\
(-8.45)\end{array}$ & -- & -- \\
\hline Log (Poroad) & -- & -- & -- & -- & -- & $\begin{array}{c}-0.4964 * * \\
(-8.71)\end{array}$ & -- \\
\hline Log (Poexp) & -- & -- & -- & -- & -- & -- & $\begin{array}{c}-0.3681^{* *} \\
(-8.39)\end{array}$ \\
\hline $\mathrm{n}$ & 36 & 36 & 36 & 36 & 36 & 36 & 36 \\
\hline Adjusted $\mathrm{R}^{2}$ & 0.61 & 0.70 & 0.64 & 0.65 & 0.58 & 0.59 & 0.57 \\
\hline $\mathrm{F}$ of the Equation & 14.6 & 46.1 & 50.0 & 157.3 & 48.9 & 49.1 & 55.7 \\
\hline D-W Statistic & 1.48 & 1.37 & 1.12 & 1.35 & 1.12 & 1.09 & 1.09 \\
\hline
\end{tabular}

$\mathrm{t}$ - statistics in parentheses below the coefficients

* - statistically significant at the .05 level

** - statistically significant at the .01 level 
In Model 7, $\log ($ Urate) has the expected negative sign but it is non-significant. Log(Alconsum) and $\log ($ Splimit $)$ have the expected positive signs and are significant at the .01 level. Kansas per capita expenditure for police protection, $\log ($ Poexp) has the theoretically expected negative sign and is highly significant.

Contemporaneous simultaneity could exist between motor vehicle fatalities and the three highway safety regulation enforcement variables. According to the results in Table 3 for Models 5, 6 , and 7, increases in the enforcement variables reduce Kansas motor vehicle fatalities. However, it could be argued that an increase in fatalities could result in an increase in police enforcement. To examine the potential for this contemporaneous simultaneity relationship, Models 5, 6, 7 are re-estimated with each of the police enforcement variables lagged one year. The coefficients of these lagged models are compared to those of Table 3. The variable symbols for the lagged police enforcement variables are $\log (\operatorname{Lpopop}), \log (\operatorname{Lporoad})$, and $\log (\operatorname{Lpoexp})$. The results are in Table 4.

An examination of Table 4 indicates that there is very little difference in the coefficients of the models with lagged and unlagged police enforcement variables. Thus, contemporaneous simultaneity apparently does not exist.

Table 4: Comparison of Model Coefficients with Police Enforcement Variables Unlagged and Lagged One Year

\begin{tabular}{|c|c|c|}
\hline \multicolumn{3}{|c|}{ Model Coefficients-Popop } \\
\hline Variable & Coefficients_-Unlagged Model & Coefficients_-Lagged Model \\
\hline Log(Urate) & -0.15 & -0.13 \\
\hline Log(Alconsum) & 1.04 & 1.06 \\
\hline $\log ($ Splimit $)$ & 0.72 & 0.65 \\
\hline Log(Popop) & -0.67 & -- \\
\hline Log(Lpopop) & -- & -0.58 \\
\hline \multicolumn{3}{|c|}{ Model Coefficients-Poroad } \\
\hline Variable & Coefficients_-Unlagged Model & Coefficients_-Lagged Model \\
\hline Log(Urate) & -0.12 & -0.11 \\
\hline Log(Alconsum) & 1.03 & 1.05 \\
\hline $\log ($ Splimit $)$ & 0.76 & 0.70 \\
\hline Log(Poroad) & -0.50 & -- \\
\hline $\log ($ Lporoad $)$ & -- & -0.44 \\
\hline \multicolumn{3}{|c|}{ Model Coefficients_-Poexp } \\
\hline Variable & Coefficients_-Unlagged Model & Coefficients_-Lagged Model \\
\hline $\log ($ Urate $)$ & -0.09 & -0.14 \\
\hline Log(Alconsum) & 0.76 & 0.91 \\
\hline $\log ($ Splimit $)$ & 0.75 & 0.76 \\
\hline $\log ($ Poexp $)$ & -0.37 & -- \\
\hline $\log (\operatorname{Lpoexp})$ & -- & -0.35 \\
\hline
\end{tabular}

\section{CONCLUSION}

This paper specifies a model of Kansas motor vehicle fatalities as a function of economic conditions, driver characteristics, government highway regulations, location of driving, and highway traffic safety law enforcement. The model is estimated in log-log specification by OLS regression in annual frequency for the 1970-2005 time period. 
The empirical results are consistent with those of previous studies. The Kansas unemployment rate, $\log ($ Urate), has the theoretically expected negative sign in all seven estimated models, but is statistically significant in only two of the models. ${ }^{4}$ Per capita alcohol consumption, Log(Alconsum), has the expected positive sign and is statistically significant at the .01 level in five of the seven estimated equations. The maximum speed limit on rural Kansas interstate highways, Log(Splimit) has a positive sign and is highly significant in all seven estimated models.

The Kansas seat belt law dummy variable, Seatbelt, has the expected negative sign and is statistically significant at the .01 level. The Kansas proportion of young plus older drivers, $\log$ (ynold), has the expected positive sign and is highly significant as is the case for the Kansas ratio of rural to urban driving, $\log$ (RUvehmile). Since Kansas motor vehicle fatalities declined during the 1970-2005 period, $\log ($ Trend) has the expected negative sign and was statistically significant at the .01 level.

This paper weighs the effect of three measures of highway safety law enforcement on Kansas motor vehicle fatalities. These measures are Kansas police per 10,000 population, Log(Popop); Kansas police per 100 miles of road, $\log ($ Poroad); and Kansas per capita expenditure for police protection, $\log ($ Poexp). All three variables have the theoretically expected negative sign and are statistically significant at the .01 level.

It is interesting to compare the results of this paper to that of a similar study of Ohio motor vehicle fatalities (Welki and Zlatoper 2007). Ohio is an urbanized eastern state with 7.7 times the population density of Kansas, a rural Midwestern state. Yet there are more similarities than differences in the determinants of motor vehicle fatalities in the two states.

Both studies find an inverse relationship between the unemployment rate and motor vehicle fatalities. However, the unemployment rate is statistically significant in only two of the seven estimated models in this paper as opposed to a highly significant relationship in all three of the estimated Ohio models. The Kansas seat belt law dummy variable is inversely related to Kansas motor vehicle fatalities and statistically significant at the .01 level in all seven models. In contrast, the Ohio seat belt law is not significant in any of the three models. ${ }^{5}$

However, there are many similarities in the findings of the two studies. Per capita alcohol consumption has a direct relationship to motor vehicle fatalities and is statistically significant in both studies. The proportion of the 15 and older population in the age 15-24 and 65 and older age groups has a positive and statistically significant relationship to motor vehicle fatalities in both studies. The maximum speed limit on rural interstate highways is positively related to motor vehicle fatalities in both Kansas and Ohio. The speed limit is highly significant in all seven of the Kansas model specifications and all three of the Ohio models. Since motor vehicle fatalities have declined nationally, the trend has a negative sign and is statistically significant in both studies.

The two studies take different approaches to measuring the impact of highway safety law enforcement. Welki and Zlatoper (2007) specify four enforcement variables, which are arrests for drunk driving, speeding, not wearing seat belts, and motor vehicle inspections. Only arrests for drunk driving are statistically significant. This study specifies different enforcement variables, primarily because no single state agency in Kansas collects statewide data for traffic law arrests or motor vehicle inspections. All three highway safety law enforcement variables in this study have the theoretically expected negative sign and are highly significant.

The empirical results suggest some transportation policy recommendations. Although these apply only to Kansas, they may suggest initiatives for transportation policymakers in other states. In Kansas, when the speed limit on interstate highways has been raised, motor vehicle fatalities have increased. However, determining the appropriate speed limit on these roads would involve a detailed assessment of the benefits in terms of avoided fatalities, injuries, and property damage resulting from a lower limit versus the costs of increased driver travel times.

The Kansas secondary seatbelt law contributed to reduced motor vehicle fatalities after its passage in July 1986. This suggests that the state should consider adopting a primary seatbelt law coupled with increased fines for failure to wear a seatbelt. 
The empirical results suggest that increased police protection, and therefore increased enforcement of traffic safety laws, reduces motor vehicle fatalities. Thus, the state should consider increasing the budget for traffic safety law enforcement.

\section{Endnotes}

1. Data obtained from U.S. Department of Transportation, Highway Statistics 2005.

2. The highway law enforcement variables represent police visibility. Greater visibility is likely to produce safer driving conditions if it is accompanied by a high likelihood of arrest. Increased arrests promote safer driving conditions if they are due to stricter police enforcement rather than an increase in illegal driving (Welki and Zlatoper 2007).

3. Seatbelt is a dummy variable and not expressed in log form since it has zero values for years in which there was no seat belt law in Kansas. The model is also estimated in non-log form with fatalities as the dependent variable. In addition, the model is estimated with the fatality rate as the dependent variable in both log and non-log form. The empirical results of these alternative estimations are virtually identical to those in Table 2.

4. The lack of statistical significance of the Kansas unemployment rate may be due to lack of variation over time. In 33 of the 36 observations in the 1970-2005 timeframe, the Kansas unemployment rate ranges between $3 \%$ and $5 \%$ in 25 cases, is between 5.0 and $5.6 \%$ in eight years, and is above $6 \%$ in only three years.

5. Kansas and Ohio both have secondary seat belt laws in which the driver can only be cited for a seatbelt violation if stopped for another traffic law violation (i.e., speeding). However, the two states could have different fines for not wearing seatbelts or different levels of police enforcement of the seatbelt law that could lead to differences between the two states regarding the impact of seatbelt laws on motor vehicle fatalities.

\section{References}

Adams, B. "Deregulation's Negative Effect on Safety.” L.N. Moses and I. Savage eds. Transportation Safety in an Age of Deregulation. New York: Oxford University Press (1989): 21-27.

Alexander, D.L. "Motor Carrier Deregulation and Highway Safety: An Empirical Analysis." Southern Economic Journal 59(1), (1992): 28-38.

Daicoff, D.W. "Deregulation and Motor Carrier Safety." Logistics and Transportation Review 24, (1988): 175-183.

Evans, L.E. Traffic Safety and the Driver. Van Nostrand Reinhold, New York, NY, 1991.

Evans, W. and J.P. Graham. "Traffic Safety and the Business Cycle." Alcohol, Drugs, and Driving 4(1), (1988): 31-38.

Fowles, R. and P.D. Loeb. "Effects of Policy-Related Variables on Traffic Fatalities: An Extreme Bounds Analysis Using Time Series Data.” Southern Economic Journal 62(2), (1995): 359-366.

Fowles, R. and P.D. Loeb. "Speeding, Coordination, and the 55 mph Limit: Comment." American Economic Review 79(4), (1989): 916-921. 
Insurance Institute for Highway Safety. Maximum Posted Speed Limits for Passenger Vehicles, as of April 2007. http://www.iihs.org/laws/state_laws/speed_limit_laws.html (accessed May 2007).

Kansas Department of Human Resources. Labor Stats. http://laborstats.dol.ks.gov (accessed May 2007).

Keeler, T.E. "Highway Safety, Economic Behavior, and the Driving Environment." The American Economic Review 84(3), (1994): 684-693.

Kraas, A. "The Impact of the U.S. Motor Carrier Act of 1980 on Road Safety in California: An Econometric Policy Evaluation.” Logistics and Transportation Review 29(2), (1993): 179-192.

Lave, C.A. "Speeding, Coordination, and the 55 mph Limit." American Economic Review 75(5), (1985): 1159-1164.

Levy, D.T. and P. Asch. "Speeding, Coordination, and the $55 \mathrm{mph}$ Limit: Comment." American Economic Review 79(4), (1989): 913-915.

Loeb, P.D. and W.A. Clarke. "The Determinants of Truck Accidents." Transportation Research Part E 43(4), (2007): 442-452.

Loeb, P.D. "The Effectiveness of Seat Belt Legislation in Reducing Driver-Involved Injury Rates in Maryland." Transportation Research Part E 37(4), (2001): 297-310.

Loeb, P.D. "The Effectiveness of Seat Belt Legislation in Reducing Injury Rates in Texas.” American Economic Review 85(2), (1995): 81-84.

Loeb, P.D., W.K. Talley, and T.J. Zlatoper. Causes and Determinants of Transportation Accidents: An Analysis by Mode. Quorom Books, Westport, CT, 1994.

Loeb, P.D. "The Effectiveness of Seat Belt Legislation in Reducing Various Driver-Involved Injury Rates in California." Accident Analysis and Prevention 25(2), (1993): 189-197.

Loeb, P.D. “Automobile Safety Inspection: Further Econometric Evidence." Applied Economics 22, (1990): 1697-1704.

Merrell, D., M. Poitras, and D. Sutter. “The Effectiveness of Vehicle Safety Inspections: An Analysis Using Panel Data.” Southern Economic Journal 65(3), (1999): 571-583.

Moore, T.G. "The Myth of Deregulation's Negative Effect on Safety.” L.N. Moses and I. Savage eds. Transportation Safety in an Age of Deregulation. New York: Oxford University Press (1989): $8-20$.

National Institute on Alcohol Abuse and Alcoholism. Per Capita Ethanol Consumption for States, Census Regions, and the United States, 1970-2004. National Institute of Health, 2007. http://www. niaaa.nih.gov/Resources/DatabaseResources/QuickFacts/AlcoholSales/Consum03 htm (accessed May 2007).

Newey, W.K. and K. West. “A Simple Positive Semi-definite Heteroskedasticity and Autocorrelation Consistent Covariance Matrix." Econometrica 55(3), (1987): 703-708.

Partyka, S.C. "Simple Models of Fatality Trends Using Unemployment and Population Data." Accident Analysis and Prevention 16(3), (1984): 211-222. 
Determinants of Motor Vehicle Fatalities

Peltzman, S. “The Effects of Automobile Safety Regulation.” Journal of Political Economy 83(4), (1975): 677-725.

President's Council of Economic Advisors. Economic Report of the President. Washington, D.C., 2007, p. 299.

Robertson, L.S. “Automobile Safety Regulation: Rebuttal and New Data.” American Journal of Public Health 74(12), (1984): 1390-1394.

State of Kansas. Annual Economic Report of the Governor, 1970-1975 issues. Topeka, Kansas, 1970-1975.

U.S. Bureau of the Census, Population Division. Annual Estimates of Population by Age and Sex for Kansas, April 1, 2000 to July 1, 2006 (SC-EST2006-02-20, 2007. http://www.census.gov (accessed May 2007).

U.S. Bureau of the Census, Population Division. Population Estimates for the U.S., Regions, and States by Five-Year Age Groups and Sex: Time Series Estimates, July 1, 1990 to July 1, 1999 and April 1, 1990 Census Counts, 2007. http://www.census.gov (accessed May 2007).

U.S. Bureau of the Census, Population Estimates Branch. Resident Population of States by FiveYear Age Group and Sex (also in Current Population Reports, Series P25-1106), 2007. http://www. census.gov (accessed May 2007).

U.S. Bureau of the Census, Population Distribution Branch. Intercensal Estimates of the Resident Population 1970 to 1980 (also in Current Population Reports, Series P25, No. 998), 2007. http:// www.census.gov (accessed May 2007).

U.S. Department of Justice, National Criminal Justice Information and Statistics Service. Sourcebook of Criminal Justice Statistics, 1973, (1974): 30-36.

U.S. Department of Justice, National Criminal Justice Information and Statistics Center. Trends in Expenditure and Employment Data for the Criminal Justice System, 1973, 1974, 1975, 1976, and 1977 issues, pages 68 and 72.

U.S. Department of Justice, Bureau of Justice Statistics. Justice Expenditure and Employment in the U.S., 1971-1979, (1980): 64, 70, and 71.

U.S. Department of Justice, Bureau of Justice Statistics. Justice Expenditure and Employment Extracts: 1982 and 1983, (1984): 3, 16, 27, 53, 68, and 79.

U.S. Department of Justice, Bureau of Justice Statistics. Justice Expenditure and Employment Extracts: 1984, 1985, and 1986, (1987): 25, 38, 49, 50, 77, 101, 129, 142, and 153.

U.S. Department of Justice, Bureau of Justice Statistics. Justice Expenditure and Employment in the U.S. 1988, (1989): 14 and 28.

U.S. Department of Justice, Bureau of Justice Statistics. Justice Expenditure and Employment Extracts: Data from the Annual General Finance and Employment Surveys, 1992-2004 issues (http://www.ojp.usdoj.gov/bjs).

U.S. Department of Transportation, National Highway Traffic Safety Administration. Traffic Safety Facts 2001: A Compilation of Motor Vehicle Crash Data from the Fatality Analysis Reporting System and the General Estimates System, 2002. 
U.S. Department of Transportation, National Highway Traffic Safety Administration. Traffic Safety Facts: A Compilation of Motor Vehicle Crash Data from the Fatality Analysis Reporting System and the General Estimates System, 1998 Edition, Table 126, p. 186.

U.S. Department of Transportation, Federal Highway Administration. Highway Statistics 1970, 1971. http://www.fhwa.dot.gov/policy/ohpi/index.htm (accessed May 2007).

U.S. Department of Transportation, Federal Highway Administration. Highway Statistics 1971, 1972. http://www fhwa.dot.gov/policy/ohpi/index htm (accessed May 2007).

U.S. Department of Transportation, Federal Highway Administration. Highway Statistics 1972, 1973. http://www.fhwa.dot.gov/policy/ohpi/index.htm (accessed May 2007).

U.S. Department of Transportation, Federal Highway Administration. Highway Statistics 1973, 1974. http://www fhwa.dot.gov/policy/ohpi/index htm (accessed May 2007).

U.S. Department of Transportation, Federal Highway Administration. Highway Statistics 1974, 1975. http://www.fhwa.dot.gov/policy/ohpi/index.htm (accessed May 2007).

U.S. Department of Transportation, Federal Highway Administration. Highway Statistics 1975, 1976. http://www fhwa.dot.gov/policy/ohpi/index htm (accessed May 2007).

U.S. Department of Transportation, Federal Highway Administration. Highway Statistics 1976, 1977. http://www.fhwa.dot.gov/policy/ohpi/index.htm (accessed May 2007).

U.S. Department of Transportation, Federal Highway Administration. Highway Statistics 1977, 1978. http://www fhwa.dot.gov/policy/ohpi/index htm (accessed May 2007).

U.S. Department of Transportation, Federal Highway Administration. Highway Statistics 1978, 1979. http://www.fhwa.dot.gov/policy/ohpi/index.htm (accessed May 2007).

U.S. Department of Transportation, Federal Highway Administration. Highway Statistics 1979, 1980. http://www.fhwa.dot.gov/policy/ohpi/index.htm (accessed May 2007).

U.S. Department of Transportation, Federal Highway Administration. Highway Statistics Summary to 1985, 1986. http://www fhwa.dot.gov/policy/ohpi/index.htm (accessed May 2007).

U.S. Department of Transportation, Federal Highway Administration. Highway Statistics 1986, 1987. http://www fhwa.dot.gov/policy/ohpi/index htm (accessed May 2007).

U.S. Department of Transportation, Federal Highway Administration. Highway Statistics 1987, 1988. http://www.fhwa.dot.gov/policy/ohpi/index.htm (accessed May 2007).

U.S. Department of Transportation, Federal Highway Administration. Highway Statistics 1988, 1989. http://www fhwa.dot.gov/policy/ohpi/index htm (accessed May 2007).

U.S. Department of Transportation, Federal Highway Administration. Highway Statistics 1989, 1990. http://www.fhwa.dot.gov/policy/ohpi/index.htm (accessed May 2007).

U.S. Department of Transportation, Federal Highway Administration. Highway Statistics Summary to 1995, 1996. http://www fhwa.dot.gov/policy/ohpi/index.htm (accessed May 2007).

U.S. Department of Transportation, Federal Highway Administration. Highway Statistics 1996, 1997. http://www fhwa.dot.gov/policy/ohpi/index htm (accessed May 2007). 
U.S. Department of Transportation, Federal Highway Administration. Highway Statistics 1997, 1998. http://www.fhwa.dot.gov/policy/ohpi/index.htm (accessed May 2007).

U.S. Department of Transportation, Federal Highway Administration. Highway Statistics 1998, 1999. http://www fhwa.dot.gov/policy/ohpi/index htm (accessed May 2007).

U.S. Department of Transportation, Federal Highway Administration. Highway Statistics 1999, 2000. http://www fhwa.dot.gov/policy/ohpi/index htm (accessed May 2007).

U.S. Department of Transportation, Federal Highway Administration. Highway Statistics 2000, 2001. http://www fhwa.dot.gov/policy/ohpi/index htm (accessed May 2007).

U.S. Department of Transportation, Federal Highway Administration. Highway Statistics 2001, 2002. http://www fhwa.dot.gov/policy/ohpi/index htm (accessed May 2007).

U.S. Department of Transportation, Federal Highway Administration. Highway Statistics 2002, 2003. http://www fhwa.dot.gov/policy/ohpi/index htm (accessed May 2007).

U.S. Department of Transportation, Federal Highway Administration. Highway Statistics 2003, 2004. http://www fhwa.dot.gov/policy/ohpi/index htm (accessed May 2007).

U.S. Department of Transportation, Federal Highway Administration. Highway Statistics 2004, 2005. http://www fhwa.dot.gov/policy/ohpi/index htm (accessed May 2007).

U.S. Department of Transportation, Federal Highway Administration. Highway Statistics 2005, 2006. http://www fhwa.dot.gov/policy/ohpi/index htm (accessed May 2007).

U.S. General Accounting Office. Highway Safety: Safety Belt Use Laws Save Lives and Reduce Costs to Society. GAO/RCED-92-106, Washington, D.C., 1992.

Viscusi, W.K. "The Effect of Transportation Deregulation on Worker Safety." L.N. Moses and I. Savage eds. Transportation Safety in an Age of Deregulation. New York: Oxford University Press (1989): 70-89.

Welki, A.M. and T.J. Zlatoper. "The Impact of Highway Safety Regulation Enforcement Activities on Motor Vehicle Fatalities.” Transportation Research Part E 43(2), (2007): 208-217.

Zlatoper, T.J. "Determinants of Motor Vehicle Deaths in the United States: A Cross Sectional Analysis." Accident Analysis and Prevention 23(5), (1991): 431-436. 
Michael W. Babcock is a professor of economics at Kansas State University (KSU). In his 35-year career at KSU, he has published more than 80 articles in professional journals along with numerous monographs and technical reports. His research has been cited in more than 75 books, the transportation press, and professional journals. He has presented nearly 90 papers at professional meetings and was principal investigator or co-investigator on 31 federal and state government research grants worth nearly $\$ 2$ million.

Babcock has been recognized five times by the Transportation Research Forum for outstanding transportation research. In 2005 he was presented the Herbert O. Whitten TRF Service Award for professional contributions to TRF.

Tom Zlatoper is professor of economics in the Department of Economics and Finance at John Carroll University. His research interests include transportation safety and sports economics. His work has been published in various journals, and he co-authored the book Causes and Deterrents of Transportation Accidents: An Analysis by Mode. He received his B.A. in mathematics and economics from Boston College and his M.A. and Ph.D. in economics from Northwestern University.

Andrew Welki received his B.A. in economics from Wilkes College and his Ph.D. in economics from Penn State University. He started his career at John Carroll University in 1982. Since then he has been a three-time recipient of the Wasmer Award for outstanding teaching in the Boler School of Business. In 2005 he received John Carroll's Distinguished Faculty Award. His research interests include sports economics and transportation safety issues. He has published articles in a number of professional journals including the Atlantic Economic Journal and Managerial and Decision Economics. He has been the faculty athletic representative for 10 years as currently serves on the executive committee of the Ohio Athletic Conference. 


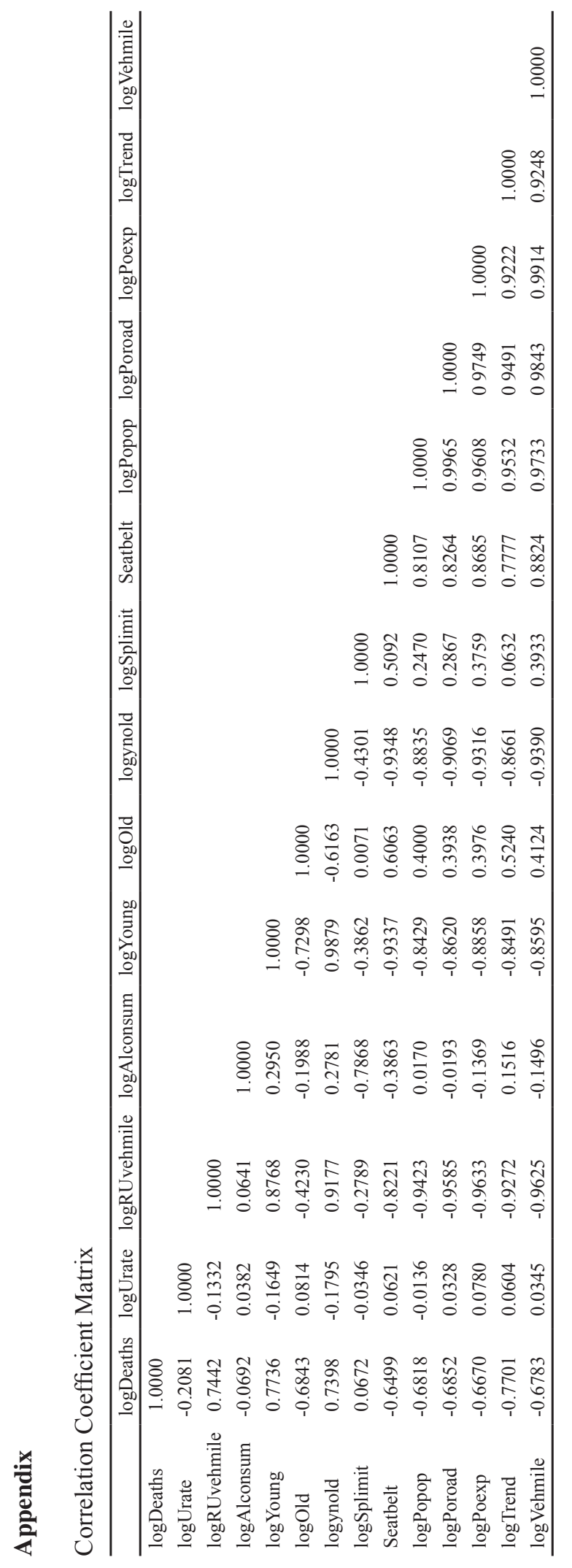

